\title{
Office-made 4\% Albendazole Cream is an Effective Alter- native Therapy for Cutaneous Larva Migrans: A Report of Three Cases
}

\author{
Rizki CITRA MULIA ${ }^{1}$, Khairuddin DJAWAD ${ }^{1 *}$, Anni ADRIANI', Idrianti IDRUS ${ }^{1}$ \\ ${ }^{1}$ Department of Dermatology and Venereology, Faculty of Medicine, Universitas Hasanuddin, Makassar, Indonesia
}

Correspondence: Khairuddin Djawad, E-mail: duddindj@gmail.com

UDC 616.5-002.951.32-085

\begin{abstract}
Introduction. Cutaneous larva migrans (CLM), commonly called creeping eruption, is a parasitic skin disorder caused by the invasion of larva to the skin. This disease classically presents as serpiginous lesions. Larva frequently originates from fecal material of cats and dogs. The pruritus is usually intense and if not treated might disrupt activity, lead to secondary infection, and extend to other regions. Oral and topical antihelminthic agents are the first-line treatment with excellent clinical response. However, they are not always readily available, as is it the case in our region. We attempt to tackle this limitation by formulating an office-made albendazole cream. This report shows the clinical efficacy of our regimen in three cases of CLM. Case Report. We report three cases of CLM diagnosed through history taking and clinical presentation. All cases were treated with topical office-made albendazole as requested by the patients and due to resource limitation. The topical preparation was made by dissolving $400 \mathrm{mg}$ albendazole tablet into sterile water and mixing it with Vaseline to form $4 \%$ cream. Three times daily application for seven days led to excellent clinical response. Conclusion. Our $4 \%$ office-made albendazole cream was shown to be effective in treating CLM. Thus, this simple and practical preparation may serve as an alternative treatment for CLM.
\end{abstract}

Key words: Larva Migrans; Skin Diseases, Parasitic; Antihelmintics; Antiparasitic Agents; Albendazole; Pruritus; Drug Compounding

\section{Introduction}

Cutaneous larva migrans (CLM) is a common helminthic dermatosis especially among travellers (1) and those frequently in contact with soil or sand who do not wear adequate foot protection (2-5). The most common infectious agents are Ancylostomabraziliense and Ancylostoma caninum with typical clinical manifestation of pruritic serpiginous and linear lesions $(3,6)$. The diagnosis of CLM is established through history taking and clinical presentation. Skin biopsy is rarely needed and reserved for atypical cases $(1,4,7,8)$.

Oral ivermectin and albendazole are the first-line treatment with excellent clinical response $(9,10)$. However, both are associated with gastrointestinal side effects and allergic reaction $(9,11)$. Thus, topical treatments, especially in localized lesions, have been advocated since 2016 and are associated with excellent improvement and minimal systemic side effects $(3,6,12)$. Topical ivermectin, albendazole, and thiabendazole are commonly used topical treatment $(6,9,13)$. Unfortunately, such topical treatments are not always readily available, as is the case in our centre. Topical ivermectin is a costly treatment while topical albendazole and thiabendazole are unavailable in our region. Albendazole is only available in $400 \mathrm{mg}$ tablet but it is often refused by patients who are concerned with the potential side effects. Thus, in order to cope with this limitation, we have attempted to formulate topical Albendazole in multiple occasions which has yielded an excellent clinical response.

Here we report three CLM cases treated by mixing $400 \mathrm{mg}$ albendazole tablet and Vaseline album three times daily with excellent clinical response after five to seven days. 


\section{Case Reports}

\section{Case 1}

A 51-year-old female came with a chief complaint of pruritic and painful erythematous serpinginous lesion on the posterior side of the left leg which had developed a week before admission. The lesion started as an erythematous bump that slowly elevated, elongated, and became increasingly pruritic. The patient denied history of travelling but recalled, as well as contact with cats and dogs. There were cats and dogs around the area. The patient was currently on multiple drugs for heart disease and refused to take another oral drug.

Dermatological examination showed erythematous, slightly elevated serpiginous lesion, crust, pustules, and hyperpigmented macules on the left femoral region (Figure 1A). Larvae were not found under the microscope. The patient was treated with our office-made topical albendazole. Control visit after seven days showed the lesion had resolved leaving hyperpigmented plaque (Figure 1B). Complete resolution was achieved after one month with no relapse until this article was written.

\section{Case 2}

A 1.5-year-old boy came with snakelike erythematous lesion on the buttocks and scrotum. The lesions started as an itchy ery- thematous bump on the buttocks which transformed into snakelike lesion that elongated progressively. The patient often played in his backyard which was full of sand and soil without wearing any clothes. There were cats and dogs around the area.

Dermatological examination showed erythematous, slightly elevated serpiginous lesion with erythematous papule on its end and hyperpigmented macules on the right gluteal region and scrotum (Figures $2 \mathrm{~A}$ and $2 \mathrm{~B}$ ). No supporting examination was done due to the classical clinical presentation.

Three days after the treatment the patient was reported to stop scratching and the lesion did not further elongate. After seven days, only hyperpigmented macule was left on the gluteus while no lesions remained on the scrotum.

\section{Case 3}

A 20-year-old female came with pruritic snakelike erythematous lesion on the upper right arm which had developed five days before admission. Initially the patient complained of an intense itching that turned into erythematous papule and progressed into elevated snakelike linear lesion. There was a history of travelling to the beach in the previous week.
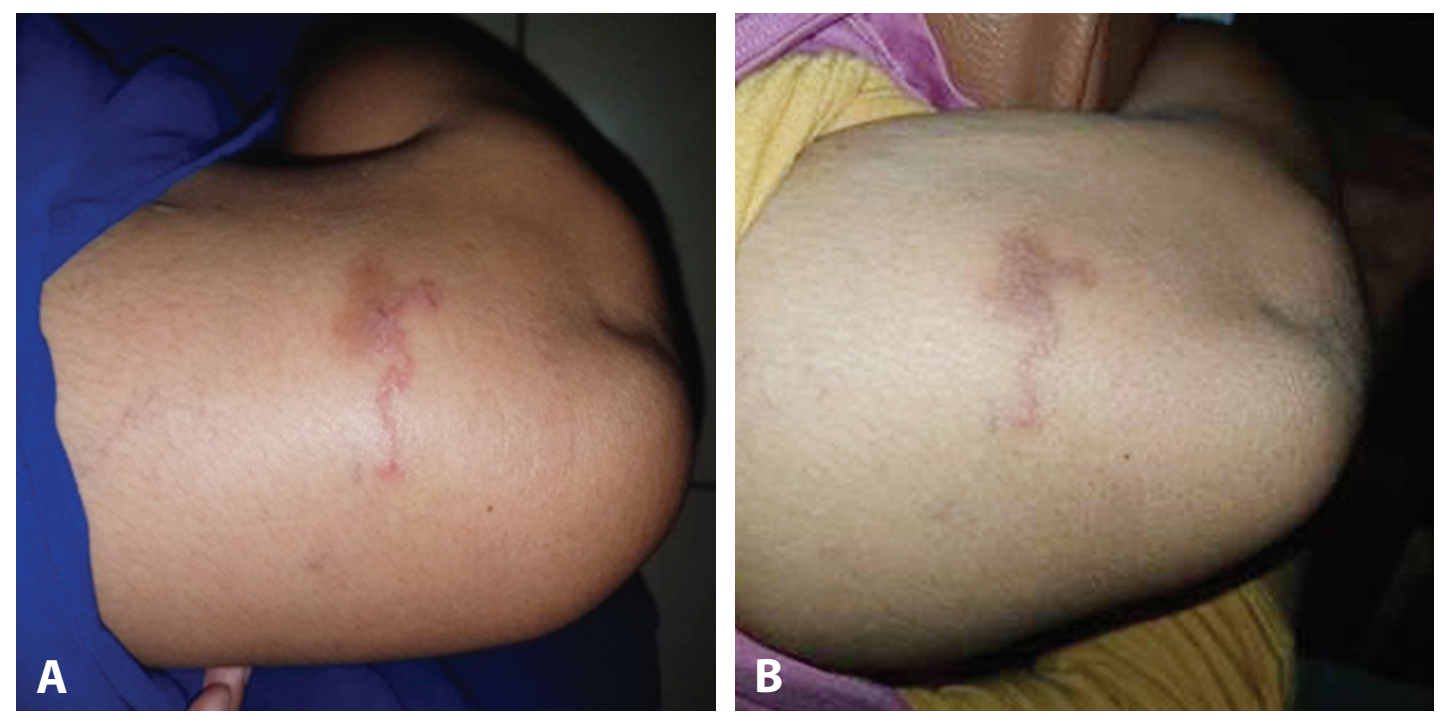

Figure 1. (A) Erythematous, slightly elevated serpiginous lesion, crust, pustules, and hyperpigmented macules on the left femoral region on day 0 (B) After 1 week of treatment, only hyperpigmented macule was left. 

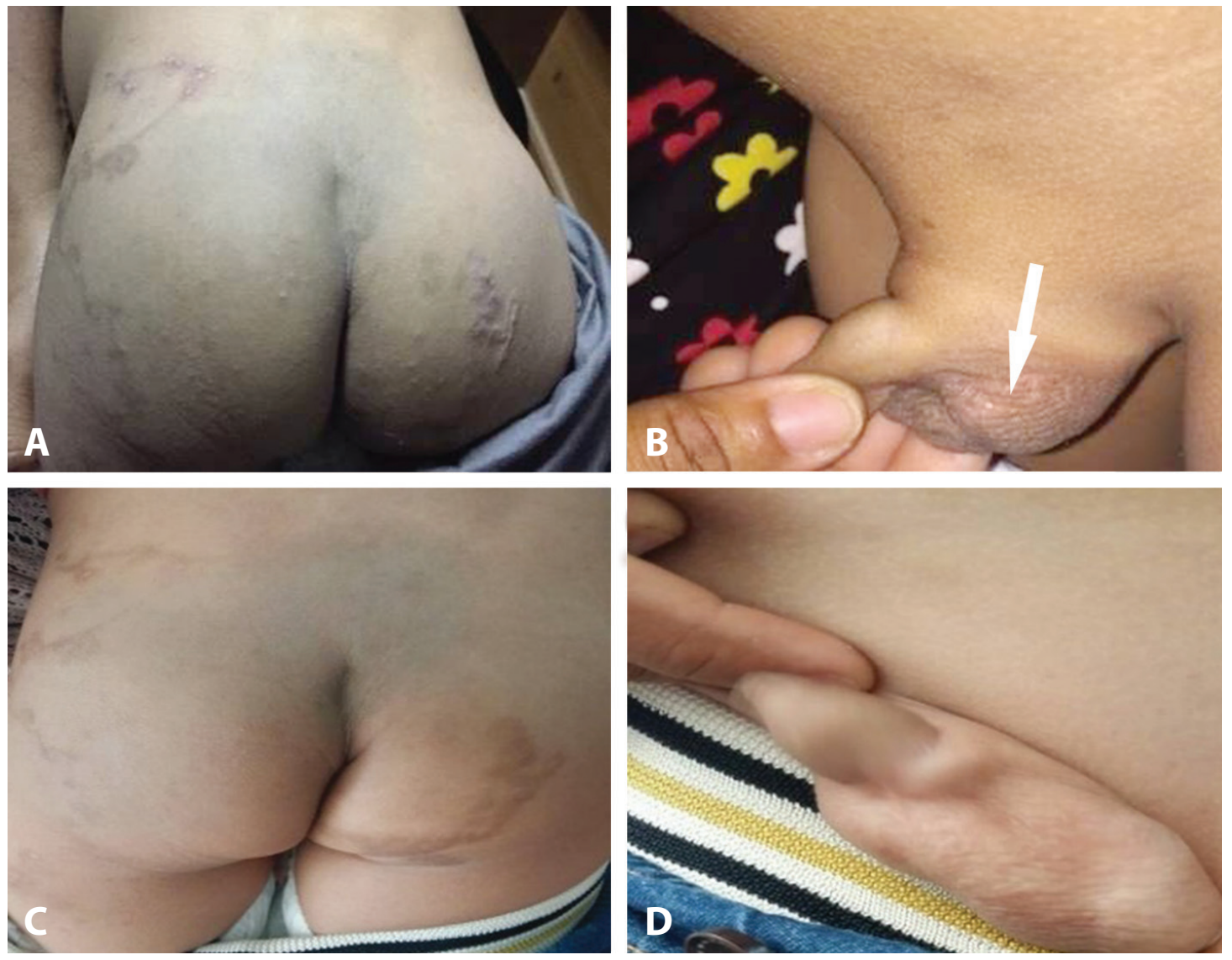

Figure 2. Erythematous, slightly elevated serpiginous lesion with erythematous papule on its end and hyperpigmented macules on the right gluteal region $(A)$ and scrotum (black arrow) (B). Follow-up on day-7 showed hyperpigmented macule on the gluteus (C) and scrotum (D).

Physical examination showed erythematous, partly hyperpigmented, slightly elevated serpiginous lesion with erythematous papule on its end on the right superior extremity (Figure 3A). Skin scraping and microscopic examination did not demonstrate larvae. A diagnosis of CLM was established through history and physical examination.

Figure 3B shows complete resolution of the lesion, leaving only hyperpigmented macule after seven days. Subjectively, the patient reported that the pruritus had ceased after two days of treatment.

All three patients were treated by administering our office-made albendazole cream. Initially, $400 \mathrm{mg}$ albendazole tablet was crushed and dissolved with sterile water. The solution was then mixed with $10 \mathrm{~g}$ vaseline album to form $4 \%$ cream. In all cases, the cream was applied three times per day.

\section{Discussion}

All three patients in our report showed a typical clinical presentation for CLM. Patients with CLM most often seek treatment due to intense pruritus and progressively elongated lesion, with or without complications, as shown in our patients $(7,8)$. Oral ivermectin and albendazole are the first-line treatment $(9,10)$. However, oral Ivermectin is not available in our area. Albendazole in $400 \mathrm{mg}$ tablet preparation was available in our center but all patients refused to take oral albendazole. Topical albendazole and thiabendazole were not available in our region while topical ivermectin is very costly and difficult to obtain.

Albendazole shows a potent antiparasitic effect against helminth infection (14). Topical treatment is gradually becoming more popular due to reported side effects of oral preparation $(9,11)$. Thus, topical application 

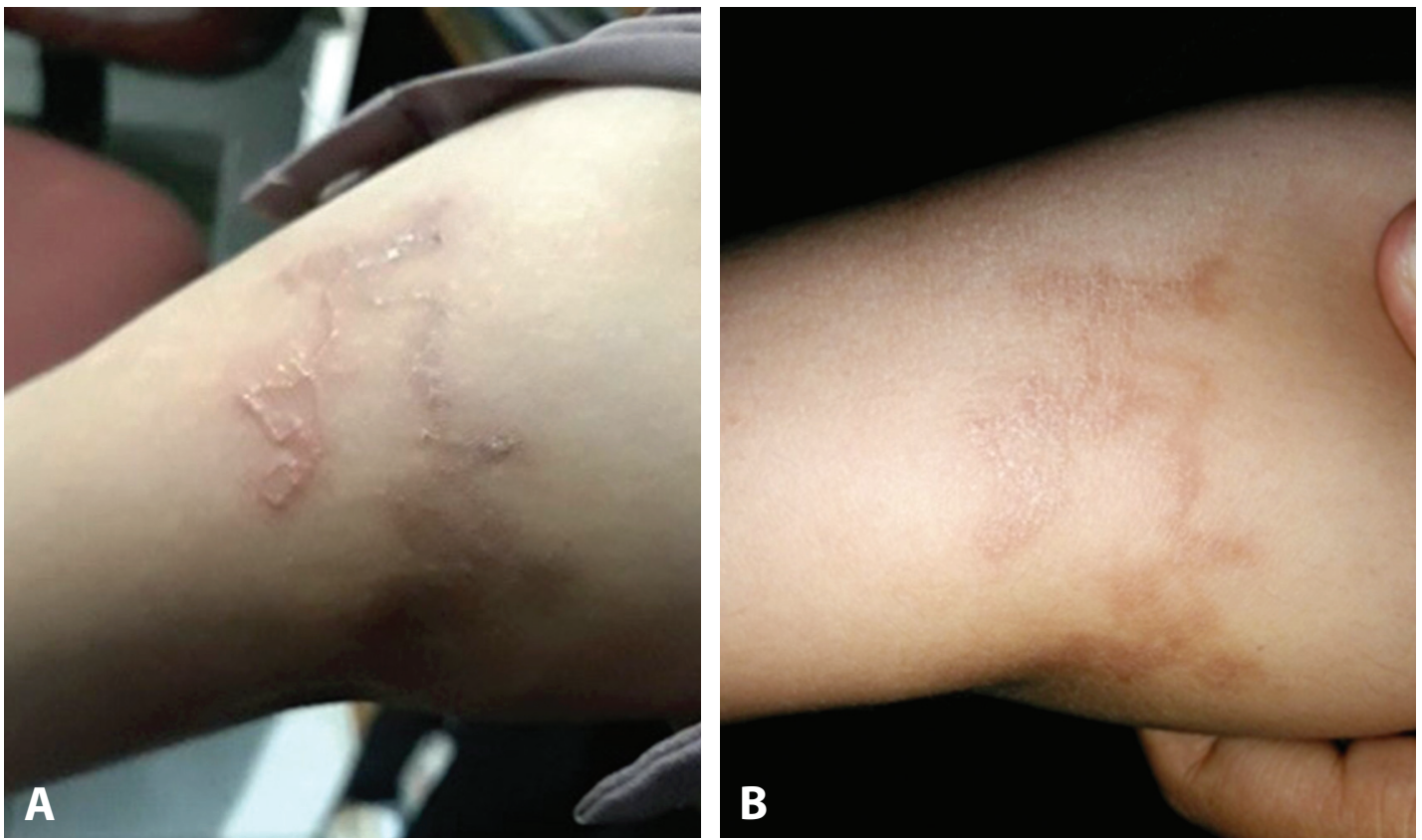

Figure 3. (A) Typical erythematous serpiginous lesionof CLM (B) resolution after seven days of treatment

is expected to result in good clinical response with minimal systemic side effects. Treatment in our three cases included our office-made topical albendazole which was simple and practical. All patients reported excellent clinical response shown by a significant decrease in pruritus and complete resolution of the skin lesion. Albendazole cream was made by crushing $400 \mathrm{mg}$ albendazole tablet and dissolving it in sterile water. The solution was then mixed with $10 \mathrm{~g}$ Vaseline album to yield a $4 \%$ cream. A similar office-made albendazole cream was mentioned in a previous report with a concentration of $10 \%$. Both cases in the report showed excellent clinical response with no relapse (15). Our report showed that pruritus, which is the main complaint in CLM, was shown to completely resolve after three days. This alternative therapeutic approach is effective in an area with no access to oral or topical anthelminthic agents and in cases where such agents are contraindicated due to risk of systemic side effects (15). This approach has been used in multiple occasions with excellent outcome after three times daily application. No relapse was found after 1-2 months of follow-up.

\section{Conclusion}

Our report showed that this office-made $4 \%$ albendazole cream applied three times daily for seven days may serve as an alternative therapy with excellent clinical outcome. This is a safe, economic, and readily accessible therapeutic approach for CLM. Larger studies are needed to assess the effectivity of this office-made regimen.

\section{Abbreviations \\ CLM - Cutaneous larva migrans}

\section{References}

1. Navrazhina K, Hibler BP, Magro CM, Wildman HF. Beach bummer: a recurrent pruritic buttocks eruption following travel. Am J Med. 2019;132(8):931-3.

2. Montgomery SP. Cutaneous larva migrans. In: Ryan ET, Hill DR, Solomon T, Aronson NE, Endy TP. Hunter's tropical medicine and emerging infectious diseases. Edinburgh: Elsevier; 2020. p. 898-900.

3. Smilga AS, Bujold J. A unique case of cutaneous larva migrans acquired within the Province of Quebec and successfully treated with topical ivermectin. J Cutan Med Surg. 2018;22(3):347-8.

4. Perić J, Lekić B, Reljić V, Ćirković L, Škiljević D. Cutaneous larva migrans - report of 2 new cases locally acquired in Serbia. Serbian Journal of Dermatology and Venereology. 2017;9(4):149-53. 
5. Tianyi FL, Agbor VN, Kadia BM, Dimala CA. An unusual case of extensive truncal cutaneous larva migrans in a Cameroonian baby: a case report. J Med Case Rep. 2018;12(1):270.

6. Gelmetti C, Brena M, Veraldi S. Hookworm related cutaneous larva migrans of the penis successfully treated with topical ivermectin. Pediatr Dermatol. 2019;36(3):391-2.

7. Brenner MA, Patel MB. Cutaneous larva migrans: the creeping eruption. Cutis. 2003;72(2):111-5.

8. Park JW, Kwon SJ, Ryu JS, Hong EK, Lee JU, Yu HJ, et al. Two imported cases of cutaneous larva migrans. Korean J Parasitol. 2001;39(1):77-81.

9. Magri F, Chello C, Pranteda G, Pranteda G. Complete resolution of cutaneous larva migrans with topical ivermectin: a case report. Dermatol Ther. 2019;32(3): e12845.

10. Quashie NB, Tsegah E. An unusual recurrence of pruritic creeping eruption after treatment of cutaneous larva migrans in an adult Ghanaian male: a case report with a brief review of literature. Pan Afr Med J. 2015;21: 285.

11. Rafat M, Afzal A, Shaukat S, Zahoor M, Hussain I. Extensive cutaneous larva migrans: a case report. Journal of Pakistan Association of Dermatology. 2018; 27(4):391-3.

12. Gerbig AW, Kempf W. Topical treatment of cutaneous larva migrans with ivermectin 1\%. Int J Dermatol. 2020; 59(1):e21-2.

13. Nazzaro G, Angileri L, Parducci BA, Veraldi S. Hookworm-related cutaneous larva migrans: our 201st patient. J Infect Dev Ctries. 2017;11(5):437-9.

14. Kim TH, Lee BS, Sohn WM. Three clinical cases of cutaneous larva migrans. Korean J Parasitol. 2006;44 (2):145-9.

15. Caumes E. Efficacy of albendazole ointment on cutaneous larva migrans in 2 young children. Clin Infect Dis. $2004 ; 38(11): 1647-8$.

\section{Efikasna alternativna terapija kutane larve migrans galenskom $4 \%$ albendazol kremom - prikaz tri slučaja}

\section{Sažetak}

Uvod. Kutana larva migrans, poznata kao "puzajuća erupcija", parazitorno je oboljenje kože izazvano invazijom larve na kožu. Ovo oboljenje se klasično manifestuje kao serpiginozne lezije. Larva često potiče iz fekalija mačaka i pasa. Pruritus je obično intenzivan i, ako se ne leči, može ometati svakodnevne aktivnosti, dovesti do sekundarne infekcije i proširiti se na druge regije. Oralni i topikalni antihelminitici su tretmant prve linije i na njih pacijenti dobro reaguju. Mi pokušavamo da rešimo taj problem tako što pravimo galensku albendazol kremu. Ovde prikazujemo efikasnost našeg režima primene kreme na tri slučaja kutane larve migrans. Prikaz slučaja. Prikazujemo tri slučaja kutane larve mi- grans, dijagnostikovane na osnovu anamneze i kliničkog pregleda. Svi slučajevi su tretirani topikalnom galenskom albendazol kremom na zahtev pacijenata i zbog ograničenih resursa. Topikalni preparat je pripremljen rastvaranjem $400 \mathrm{mg}$ albendazol tablete u sterilnoj vodi i mešanjem sa vazelinom da bi se dobila $4 \%$ krema. Krema je aplicirana tri puta dnevno tokom sedam dana što je dalo dobre rezultate. Zaključak. Pokazalo se da je naša galenska $4 \%$ albendazol krema efikasna u lečenju kutane larve migrans, i da ovaj jednostavan i praktičan preparat može da posluži kao alternativni tretman kutane larve migrans.

Ključne reči: Larva migrans; Parazitske kožne bolesti; Antihelmintici; Antiparazitski lekovi; Albendazol; Pruritus; Priprema farmaceutskih preparata

Received 7.01.2020.

Accepted 27.03.2020. 